\title{
Container and Landscape Planting Depth and Root Ball Shaving Affects Magnolia grandiflora Root Architecture and Landscape Performance
}

\author{
Edward F. Gilman, Maria Paz, and Chris Harchick
}

\begin{abstract}
Plants were grown in a $2 \times 2$ factorial combination of planting depth in nursery containers and at a landscape installation to study effects on root architecture, growth, and mechanical stability of Magnolia grandiflora L. Planting depth into containers or landscape soil had no impact on bending stress to tilt trunks 40 months after landscape planting, and impacted neither trunk diameter nor tree height growth 68 months later. Trees planted $128 \mathrm{~mm}$ deep into $170 \mathrm{~L}$ containers had more circling roots at landscape planting and 68 months later than trees planted shallow in containers. Root pruning at landscape planting reduced the container imprint rating on the root system to one-third of that absent root pruning with only a $4 \mathrm{~mm}$ reduction in trunk diameter growth over 68 months. Improvement in root architecture from root pruning likely outweighs the rarely encountered downside of slightly less anchorage in an extreme weather event simulated by winching trunks. Trees planted $5 \mathrm{~cm}$ above grade were slightly-but significantly-less stable in landscape than trees planted deeper (10 cm below grade). Root pruning at planting to remove roots on root ball periphery appeared to improve root architecture while only slightly impacting growth and anchorage.

Key Words. Anchorage; Bending Stress; Circling Roots; Magnolia grandiflora; Nursery Containers; Planting; Root Pruning.
\end{abstract}

In recognition of potential problems of planting the root collar too deeply in the root ball, the ANSI Z60 American Standard for Nursery Stock beginning in 2004 (Anonymous 2004) does not consider soil above the root collar as part of root ball depth. There is good evidence for reduced or equal growth rate in the nursery when the root collar is installed deeply in container substrate depending on study location, planting depth, and taxa (Browne and Tilt 1992; Fare 2005; Giblin et al. 2005; Byran et al. 2010; Harris and Day 2010). Gilman and Harchick (2008) and Harris and Day (2010) showed that certain taxa generate adventitious roots from the buried stem in the nursery container or in the early years after landscape planting from small containers. They agreed that adventitious roots may function to aid in establishment of certain deeply planted young trees, although some taxa do not appear to have the capacity to grow new roots from the buried stem (Lyons et al. 1987). Trees can lose capacity to generate adventitious roots as they grow. This suggests that some trees planted from large containers, such as those used in the landscape profession, could have many or most of their structural roots deflected by the container wall, even on trees capable of forming adventitious roots when young. Other than Gilman and Weise (2012), there is little published on impacts of root collar depth in a nursery container on the relationship between root architecture and tree anchorage in the landscape.

There is some evidence that planting deeply when installing certain taxa into a landscape reduces survival or growth rates (Arnold et al. 2007). However, Bryan et al. (2010), Day and Harris (2008), and Gilman and Weise (2012) showed that height and trunk diameter growth after landscape planting was little affected by root collar depth. It could be that many research site soils drain well or have other attributes that mask impacts of deep planting that might display in poor soil. However, Day and Harris (2008) found that despite lack of a growth effect from deep plant- 
ing, flooding of trees planted deeply seven years earlier subjected them to increased physiological stress compared to shallowly planted trees.

Lyons et al. (1983) found that after two years, Malus pumila (Mill.) was less likely to be shaken loose by wind when installed in field soil at nursery depth than when planted up to $20 \mathrm{~cm}$ below nursery depth. The increase in anchorage of naturally regenerated roots compared to trees planted from propagation-sized containers has been shown to diminish over time for a number of species as roots grow in strength to compensate for irregular root architecture (Nichols and Alm 1983; Coutts et al. 1999). There is limited anchorage data available for trees planted from larger landscapesized containers; one shows little impact from planting depth (Gilman and Grabosky 2011).

Removing defects by pruning roots when trees of at least nine taxa were shifted to the next larger size container dramatically reduced the number of trees grading as culls (Anonymous 2015) in nursery containers (Harris et al. 1971; Gilman et al. 2010b). Less is known about the influence of root remediation (i.e., removal of roots growing over the root collar or from the side of the root ball) at landscape planting on growth, root architecture, health, and anchorage. Harris and Day (2010) showed that root remediation at planting had little impact on post-planting growth. Two studies found a significant but small increase in anchorage when root ball sides were shaved of peripheral roots at planting (Gilman and Wiese 2012; Gilman 2013). Experience with one species (Acer platanoides L.) showed that remediation a decade or more after planting was much more difficult and may be ineffective (Tate 1980; Watson and Clark 1993), implying that it would be advisable to remediate sooner. Early remediation (beginning at planting) may require fewer inputs and be more effective.

Objectives of the present study were to compare anchorage (lateral stability), surface root architecture, and growth on container-grown trees produced in a nursery with different planting depth strategies subjected to various root pruning methods and planting depths when installed into landscape soil. Magnolia grandiflora was chosen because it is designed into many temperate landscapes in North America and Europe.

\section{MATERIALS AND METHODS}

\section{Nursery Production and Landscape Planting}

In June 2005, 104 rooted cuttings of Magnolia grandiflora L. Miss Chloe ${ }^{\varpi}$ in $8 \mathrm{~cm}$ square propagation containers were planted into $11 \mathrm{~L}$ containers either with the topmost root just under (approximately $13 \mathrm{~mm}$ ) the surface or $64 \mathrm{~mm}$ below the surface. In January 2006, trees were shifted into $57 \mathrm{~L}$ containers whereby half the trees for each $11 \mathrm{~L}$ planting depth were positioned shallowly (11 L substrate surface even with $57 \mathrm{~L}$ substrate surface) and half were planted deep (11 L substrate surface $64 \mathrm{~mm}$ below $57 \mathrm{~L}$ substrate surface). A total of four nursery planting depth combinations resulted from the two planting sessions. In February 2007, all 104 trees were shifted into $170 \mathrm{~L}$ containers so that substrate surface of the $57 \mathrm{~L}$ was even with surface in the 170 $\mathrm{L}$ container. Trees were not root pruned at any time during production. Trees were arranged in a randomized complete block design with 26 replicate blocks of the four treatment combinations. Complete nursery tree production materials and methods were described elsewhere (Gilman et al. 2010a).

In September 2008, 12 trees with trunk caliper (measured $15 \mathrm{~cm}$ from substrate surface) closest to the mean caliper for each nursery planting depth treatment in $170 \mathrm{~L}(47 \mathrm{~cm}$ tall, $61 \mathrm{~cm}$ top diameter) containers $(12 \times 4=48$ trees total $)$ were planted in six rows of eight trees into Millhopper fine sand (loamy, siliceous, hyperthermic Grossarenic Paleudults) with less than $2 \%$ organic matter and a bulk density of $1.51 \mathrm{~g} / \mathrm{cc}$ in Gainesville, Florida, U.S. (USDA Hardiness Zone 8b, mean low temperature $-9^{\circ} \mathrm{C}$ ). The substrate surface was positioned $5 \mathrm{~cm}$ above landscape soil surface on half of the trees from each of the four nursery planting depth treatment combinations. Substrate surface was $10 \mathrm{~cm}$ below the soil surface on the remaining 24 trees, resulting in eight planting depth treatment combinations.

Planting holes were dug 10 to $15 \mathrm{~cm}$ wider than the root balls and with straight sides and flat bottoms. One person packed the bottom of holes by foot in an effort to standardize settling. Once the root ball was placed in the planting hole, a $15 \mathrm{~cm}$ wide volume of undisturbed soil at the edge of hole was pushed into the hole. The rest of the void around the root ball was filled with soil from the planting hole. Root 
pruning treatment was applied after backfill soil was tamped into place nearly to the top of the root ball. The two root pruning treatments were: 1 ) no root pruning; and 2) root ball shaved by inserting a sharp, square-tip balling spade to the full extent of the 35 $\mathrm{cm}$ long straight blade into the root ball top surface tangent to the trunk 4 to $5 \mathrm{~cm}$ inside the periphery (Figure 1). There were a total of 16 treatment combinations (4 planting depths in containers $\times 2$ landscape planting depths $\times 2$ root pruning treatments at planting), with three replicate blocks totaling 48 trees. The 48 trees were arranged $3 \mathrm{~m}$ apart in rows $3.8 \mathrm{~m}$ apart in a randomized complete block design.

Water was added to settle backfill soil, and soil was tamped lightly by foot to standardize compaction. No berm or water ring was constructed around the root balls. Trees were mulched in a $1.6 \mathrm{~m}$ wide strip up to the trunk along each row immediately after planting with a mixture of aged wood chips, bark, and leaves from a local line-clearance contractor, which is common in many North American landscapes. Trees that were planted high were mulched with $5 \mathrm{~cm}$ on the root ball and $10 \mathrm{~cm}$ outside the ball; in addition to the $10 \mathrm{~cm}$ of soil, those planted deeply had $10 \mathrm{~cm}$ mulch over the ball and outside the ball. Vegetation between rows was mowed periodically; weeds in mulch were kept in check with three or four annual applications of glyphosate (isopropylamine salt, 41\%). Trees were irrigated daily through three Roberts Spot-Spitters (Roberts Irrigation Products, Inc., San Marcos, Idaho, U.S.) positioned at the edge of the root ball directed toward the trunk. Thirty liters of irrigation were applied daily through 2008 and then

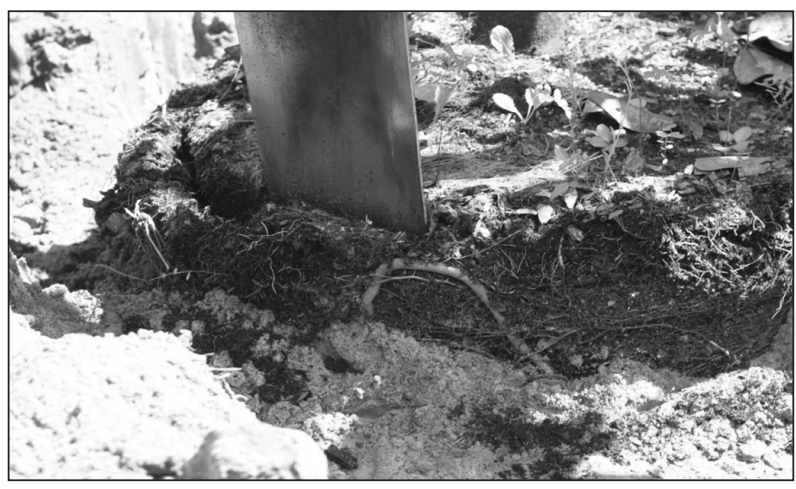

Figure 1. Shaving the root ball at planting (note root pruning spade cutting roots from outer 4 to $5 \mathrm{~cm}$ of root ball) after backfill was added to the planting hole. Removed roots and substrate were left in place as shown. Trunk is visible at top of photo, to the right of the pruning spade. reduced to $15 \mathrm{~L}$ through 2010 . Fifteen liters were applied three times weekly through January 2012. Trees were fertilized after landscape planting with $400 \mathrm{~g}$ of 16-4-8 in November 2008, and March and June 2009, and with $400 \mathrm{~g}$ of 20-0-8 in March and May 2010, March and June 2011, and April 2012.

\section{Tree Measurements}

Radius of the root system was measured from trunk to root tips by gentle hand tool excavation of surface soil (top several $\mathrm{cm}$ ) on the east and west sides (i.e., in the mulch strip) of each tree in May and November 2009; this was compared to tree crown radius (trunk to leaf tips) in the same directions to calculate root to crown spread ratio. Trunk diameter (using a diameter tape) and tree height (from mulch surface to topmost bud) were measured annually in September.

June 2014 (68 months after planting), an air excavation device was used to expose roots in the top 15 $\mathrm{cm}$ in a $50 \mathrm{~cm}$ radius 360 degrees around the trunk. Several attributes were measured, including 1) percent of trunk circumference with roots $(>10 \mathrm{~mm}$ diameter) growing tangent to, circling, or embedding into trunk; 2) root circling visual rating represented by amount of roots crossing over root collar or main lateral roots-two evaluators calibrated these ratings immediately prior to recording data by viewing every exposed root system and agreeing on a 1 value for the least (no or only small roots growing over root collar), 2 for some, 3 for abundant, 4 for many, and a 5 for the most roots growing over the collar; 3 ) imprint visual rating on the root system from deflection in $170 \mathrm{~L}$ containerstwo evaluators calibrated these ratings immediately prior to recording data by viewing every exposed root system and agreeing on a 1 value for the least (no or only small roots deflected by container), 2 for some, 3 for moderate, 4 for strong, and a 5 for most roots deflected by the container (and many of them large); 4) distance from mulch surface to the root collar; 5) diameter of roots $>10 \mathrm{~mm}$ diameter growing up at more than a 20 degree angle to the horizontal [diameter was measured top-to-bottom and side-to-side, and the mean of these two measurements was used as the diameter of a circle to calculate the cross-sectional area (CSA) of each root]. Root circling and imprint ratings were both visually estimated by two observers individually and their ratings averaged prior to statistical analysis. 


\section{Evaluating Anchorage}

Trees were winched to test anchorage in January 2012 (40 months after planting) from a point approximately $1 \mathrm{~m}$ from ground (procedure detailed in Gilman and Grabosky 2011) until the trunk base tilted five degrees. Trees were held for one minute at five degrees tilt during which time distance from the trunk to lowest point of the root plate on leeward side was measured and recorded as hinge point. When the winch was released, final angle at the trunk base was compared to vertical start angle to calculate rest angle. No rain occurred during the three days (one block of 16 trees daily) required to winch all 48 trees.

\section{Statistical Analysis}

Data were analyzed in a randomized complete block design with one tree from each nursery planting depth $(4) \times$ landscape planting depth (2) $\times$ root pruning at landscape planting (2) combination in each of three blocks. Three-way analysis of variance in the GLM procedure within SAS (SAS Institute, Cary, North Carolina, U.S.) was used to evaluate impact of main effects and interactions on measured attributes for each year independently. The GENMOD procedure was used to analyze ratings using Poisson distribution with log link function. The three main effects were planting depth into containers, planting depth at landscape planting, and root pruning at planting. Means of significant main effects were separated with Duncan's multiple range test; those with interactions by LS Means. Significant results were reported at $P<0.05$ unless indicated.

\section{RESULTS AND DISCUSSION}

Three-way interactions were insignificant for all measured attributes of growth and anchorage. With one exception described herein, two-way interactions were also insignificant. Main effects will mostly be described.

\section{Nursery Planting Depth}

Bending stress to winch trees up to five degrees trunk tilt 40 months after landscape planting was not impacted by planting depth into nursery containers (data not shown), similar to Quercus virginiana Mill. (Gilman and Weise 2012). Planting deeply into nursery containers had a neg- ligible impact (3 mm less, Gilman et al. 2010a) on trunk diameter of these trees while in $170 \mathrm{~L}$ nursery containers, and had no impact on any measurement of growth (trunk diameter and tree height) up to 68 months after planting into the landscape (data not shown). Others have also shown a small impact of planting depth in nursery containers on two year's post-planting growth (Bryan et al. 2010; Gilman and Wiese 2012). This may be the reason many growers have not recognized planting depth as a horticultural issue.

Despite no growth differences after landscape planting attributable to planting depth in nursery containers (data not shown), trees planted $128 \mathrm{~mm}$ deep $(64+64 \mathrm{~mm})$ into $57 \mathrm{~L}$ nursery containers and finished in $170 \mathrm{~L}$ containers had more roots growing tangent to and touching trunk bark at landscape planting (Gilman et al. 2010a) and 68 months after planting (Table 1) than trees planted shallowly in containers. This indicated that tangent and circling roots present at landscape planting persisted 68 months later. Root pruning by shaving the $170 \mathrm{~L}$ root ball at landscape planting did not affect this (root pruning $\times$ nursery planting depth not significant, $P>0.20$ ), indicating that shaving did not correct root deformations on the interior of the root ball. Defects over the root collar must be remediated at planting by removing roots at the top of the root ball (Harris and Day 2010). Few roots appeared to emerge from the buried portion of the trunk or root collar, also noted on the same set of trees in $170 \mathrm{~L}$ containers at planting (Gilman et al. 2010a). Moreover, root circle rating 68 months after landscape planting was higher (indicating more circling roots) when trees were planted deeply in containers than shallow regardless of landscape planting depth (Table 1). This data adds to existing evidence that the root collar in nursery containers (Harris and Day 2010; Gilman et al. 2015) and in field nurseries (Hewitt and Watson 2009) should be close to the substrate surface, especially for trees not capable of forming new roots from the root collar after planting. In apparent contrast, certain species capable of generating adventitious roots along the buried stem when planted into field soil from propagation containers (Schwan 1994) perform best when planted a few $\mathrm{cm}$ deep. Young seedling-sized trees of those taxa can continue forming adventitious roots after planting- 
Table 1. Effect of planting depth into $11 \mathrm{~L}$ and $57 \mathrm{~L}$ nursery containers on root circling 68 months after planting $170 \mathrm{~L}$ containers into landscape soil.

\begin{tabular}{lll}
\hline $\begin{array}{l}\text { Depth into } 11,57, \text { and } 170 \mathrm{~L} \\
\text { nursery container }{ }^{\mathrm{z}}(\mathrm{mm})\end{array}$ & $\begin{array}{l}\text { Percent trunk circumference with } \\
\text { tangent or circling roots }(>10 \mathrm{~mm} \\
\text { diameter) touching trunk }(\%)\end{array}$ & $\begin{array}{l}\text { Root circling rating over } \\
\text { root collarx }(1 \text { to 5) }\end{array}$ \\
\hline $13 / 0 / 0$ & $2 \mathrm{~b}^{\mathrm{w}}$ & $2.6 \mathrm{~b}$ \\
$13 / 64 / 0$ & $8 \mathrm{~b}$ & $4.2 \mathrm{a}$ \\
$64 / 0 / 0$ & $8 \mathrm{~b}$ & $3.9 \mathrm{ab}$ \\
$64 / 64 / 0$ & $22 \mathrm{a}$ & $4.8 \mathrm{a}$ \\
\hline
\end{tabular}

${ }^{\mathrm{z}}$ Point where the topmost root emerged from trunk planted at indicated distance below substrate surface into three container sizes; $20 \mathrm{~cm}$ tall liners in square propagation containers originally planted into $11 \mathrm{~L}$ nursery containers.

y Percent of trunk circumference with roots $>10 \mathrm{~mm}$ diameter growing tangent to or circling trunk that touched or were embedded into trunk bark.

${ }^{\mathrm{x}} 1=$ no roots to 5 = many roots crossing over root collar and main lateral roots.

${ }^{w}$ Numbers followed by a different letter within columns are statistically different at $P<0.03 ; \mathrm{n}=12$, averaged across landscape planting depth and root pruning due to insignificant interactions $(P>0.13$ and $>0.45$, respectively) with depth in the nursery container.

a capacity often lost among older trees planted from shade tree nurseries (Lyons et al. 1987).

\section{Root Ball Shaving}

Root ball shaving - which removed roots from the periphery of the root ball as trees were planted into the landscape-statistically decreased trunk diameter growth three (2011) and four (2012) years after planting, but the small differences $(3$ $\mathrm{mm}$ and $4 \mathrm{~mm}$, respectively) may be of little practical importance (Table 2). Tree height increase the first year after planting was suppressed $10 \mathrm{~cm}$ as a result of root ball shaving; however, there was no difference in height increase after that (data not shown). Earlier studies measured impacts of root pruning on trees less than two years old at planting; some found reduced growth (Arnold and Young 1991; Arnold 1996), increased growth (Krasowski and Owens 2000), or were unaffected (Persson 1978). Tree age, soil, irrigation management, and weather likely account for at least some of the variation in results among these studies. Recent studies on larger, landscape-sized trees showed there was little impact on post-planting growth from root remediation when planting 57 or 170 L containers (Harris and Day 2010; Gilman et al. 2015). Combined with the current data, this suggests that practitioners can feel fairly confident that long-term growth will see little impact from root pruning done to remediate root defects at planting of these taxa and size under these conditions.

A more striking change occurred in root system architecture as a result of root ball shaving. The visual container imprint rating on the root system in response to root pruning was cut to one-third of that without root pruning (Table 2). A lesser imprint has been associated with improved root systems (Salonius et al. 2000; Weicherding et al. 2007; Gilman and Harchick 2014). In apparent contrast, percent trunk circumference with tangent or circling roots touching the trunk increased by threefold in response to shaving. This may have been a response to removing all roots at the periphery of the root ball, which invigorated existing roots proximal to the cut. Some of these roots were likely already growing tangent to and close to or against the trunk, although this was not measured. Invigoration of existing roots proximal to root pruning cuts has been found previously on other taxa (Watson and Sydnor 1987; Gilman and Kane 1990). Although not measured, no tangent or circling roots appeared to arise from new roots growing from cut root ends. Root ball shaving may be combined with root remediation at the top of the root ball to reduce occurrence of circling and tangent roots (Harris and Day 2010; Gilman et al. 2015).

Root pruning by shaving root balls at planting reduced bending stress (by approximately 15\%) required to winch trees up to five degrees trunk tilt 40 months after landscape planting (Figure 2), and shaved trees had $10 \%$ greater rest angle ( 1.0 versus 0.9 degrees, Table 2) after winching to five degrees than trees not shaved. This suggests a measurable reduction in anchorage as a result of shaving exhibited by increased trunk rest angle. Winching to five degrees probably represented an extreme wind event rarely encountered in most landscapes according to winching tests calibrated to wind speed on slightly larger trees of another taxon (Gilman and Masters 2010). Previous studies on other taxa showed various root pruning treatments at landscape planting either increased anchorage by 
Table 2. Effect of root pruning root balls from $170 \mathrm{~L}$ containers at landscape planting in September 2008 on landscape growth and anchorage.

\begin{tabular}{|c|c|c|c|c|c|}
\hline Root pruning ${ }^{z}$ & $\begin{array}{l}\text { Trunk diameter } \\
\text { increase } 2011^{\mathrm{y}} \\
(\mathrm{mm})\end{array}$ & $\begin{array}{l}\text { Trunk diameter } \\
\text { increase } 2012^{\mathrm{y}} \\
(\mathrm{mm})\end{array}$ & $\begin{array}{l}\text { Percent trunk with tangent/ } \\
\text { circling roots ( }>10 \mathrm{~mm} \\
\text { diameter) touching trunk }\end{array}$ & $\begin{array}{l}\text { Root ball imprint } \\
\text { rating }^{\mathrm{w}}(1-5)\end{array}$ & $\begin{array}{l}\text { Rest angle }^{v} \\
\text { (degrees) }\end{array}$ \\
\hline None & $45 \mathrm{au}$ & $57 \mathrm{a}$ & $5 \mathrm{~b}$ & $3.6 \mathrm{a}$ & $0.9 \mathrm{~b}$ \\
\hline Shaved & $41 \mathrm{~b}$ & $54 \mathrm{~b}$ & $15 \mathrm{a}$ & $1.2 \mathrm{~b}$ & $1.0 \mathrm{a}$ \\
\hline
\end{tabular}

${ }^{\mathrm{z}}$ Root pruning removed (shaved) the outer $3 \mathrm{~cm}$ of the $170 \mathrm{~L}$ root ball periphery prior to planting into landscape soil.

${ }^{y}$ Not significant $(P>0.19)$ for the years 2009 and 2010; trees installed September 2008.

${ }^{x}$ Percent of trunk circumference with roots $>10 \mathrm{~mm}$ diameter growing tangent to or circling trunk that touched or were embedded into trunk bark.

w Imprint on the root system from deflection from $170 \mathrm{~L}$ container, where $1=$ no imprint and 5 = high imprint; rating visually estimated by two observers individually.

$\checkmark$ Trunk angle after releasing winch from 5 degree trunk pull 40 months after planting.

${ }^{u}$ Numbers followed by a different letter within columns are statistically different at $P<0.05 ; \mathrm{n}=24$, averaged across container planting depth and landscape plant-

ing depth due to insignificant interactions $(P>0.06$ and $>0.19$, respectively) with root pruning.

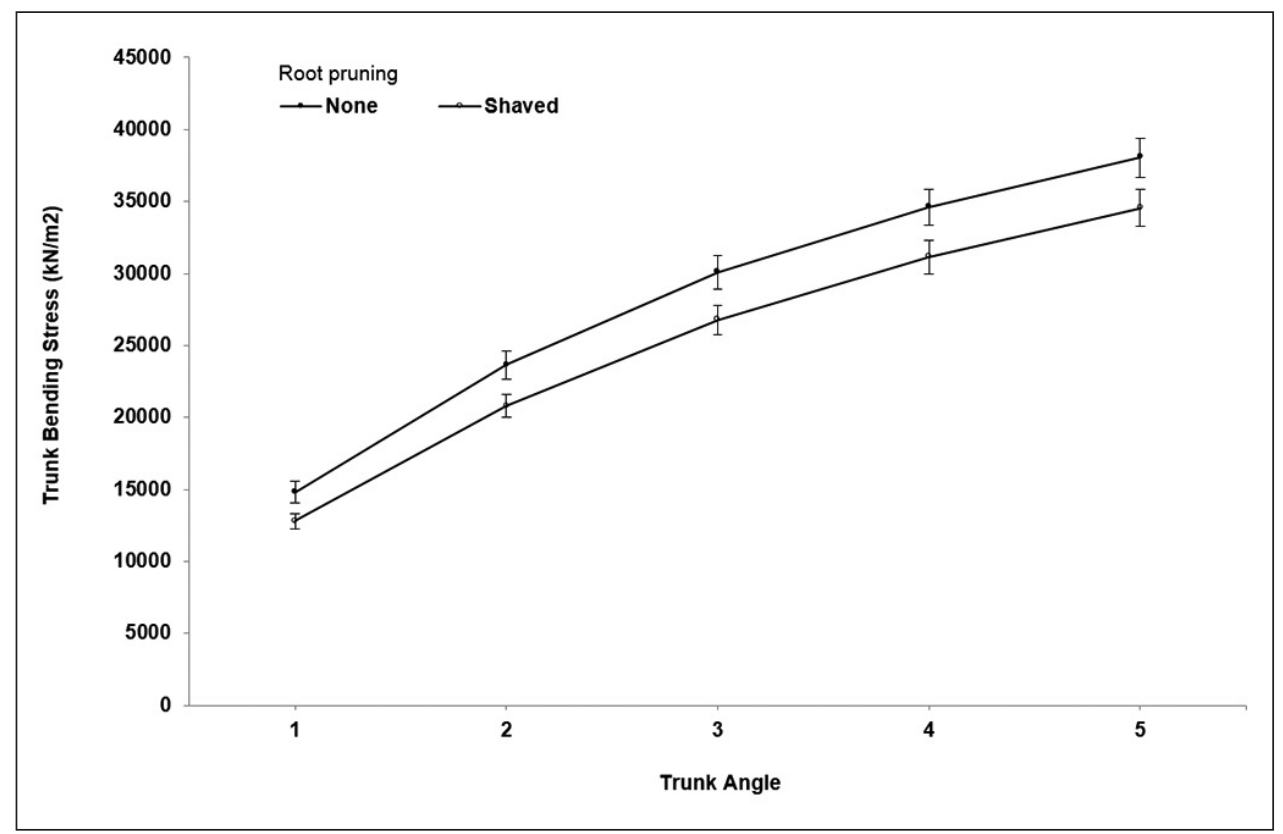

Figure 2. Bending stress required to winch trunks up to five degrees tilt 49 months after planting. Differences were significant for each angle at $P<0.05$.

Table 3. Effect of planting depth in the nursery container and root pruning at landscape planting on root growth 68 months later.

\begin{tabular}{|c|c|c|}
\hline $\begin{array}{l}\text { Depth into } 11,57 \text {, and } 170 \mathrm{~L} \\
\text { nursery container }{ }^{2}(\mathrm{~mm})\end{array}$ & Root pruning ${ }^{y}$ & $\begin{array}{l}\text { Total CSA roots }>10 \mathrm{~mm} \text { diameter } \\
\text { growing up }>20 \text { degree angle outside } \\
170 \mathrm{~L} \text { container root ball }\left(\mathrm{mm}^{2}\right)\end{array}$ \\
\hline $13 / 0 / 0$ & $\begin{array}{l}\text { None } \\
\text { Shaved }\end{array}$ & $\begin{array}{l}866 b^{x} \\
706 b\end{array}$ \\
\hline $13 / 64 / 0$ & $\begin{array}{l}\text { None } \\
\text { Shaved }\end{array}$ & $\begin{array}{l}847 \mathrm{~b} \\
738 \mathrm{~b}\end{array}$ \\
\hline $64 / 0 / 0$ & $\begin{array}{l}\text { None } \\
\text { Shaved }\end{array}$ & $\begin{array}{l}696 \mathrm{~b} \\
909 \mathrm{~b}\end{array}$ \\
\hline $64 / 64 / 0$ & $\begin{array}{l}\text { None } \\
\text { Shaved }\end{array}$ & $\begin{array}{l}525 \mathrm{~b} \\
1517 \mathrm{a}\end{array}$ \\
\hline
\end{tabular}

${ }^{2}$ Point where the topmost root emerged from trunk planted at indicated distance below substrate surface into three container sizes; $20 \mathrm{~cm}$ tall liners in square propagation containers originally planted into $11 \mathrm{~L}$ nursery containers.

${ }^{y}$ Root pruning removed (shaved) the outer $3 \mathrm{~cm}$ of the $170 \mathrm{~L}$ root ball periphery prior to planting into landscape soil.

${ }^{x}$ Numbers followed by a different letter within columns are statistically different at $P<0.05 ; \mathrm{n}=6$, averaged over landscape planting depth due to insignificant interaction with landscape planting depth $(P=0.25)$. 
$10 \%$ to $15 \%$ when planting from containers of various sizes (11 L, Gilman and Paz 2014; 57 L, Gilman and Wiese 2012; 230 L, Gilman 2013) or had no effect (170 L, Gilman et al. 2015). Improvement in root architecture, expressed by a dramatic reduction in root system imprint (Table 2), likely outweighs - in the long-term - the rarely encountered downside of slightly less anchorage in an extreme weather event occurring 40 months after planting.

Root pruning increased root CSA growing up at more than a 20 degree angle for both landscape planting depths, but only for trees planted 64 $\mathrm{mm}$ deep in both nursery container sizes (total $128 \mathrm{~mm}$ deep, Table 3). Soil conditions for root growth from trees planted at shallower depths may have been suited for horizontal growth; lower oxygen availability deeper in the profile may have been the impetus for more roots growing up at an angle (Coutts and Nicolle 1991). This response from root pruning could enable establishment under certain soil conditions by quickly generating roots closer to the soil surface compared to trees not able to generate surface roots quickly.

\section{Landscape Planting Depth}

Like Ulmus parvifolia Jacq. from a container (Bryan et al. 2010) and Corylus colurna L. from a field nursery (Day and Harris 2008), landscape planting depth had a negligible effect on magnolia trunk growth and height growth in the 68 months after planting (Table 4). In contrast, other researchers
(Lyons et al. 1987; Arnold et al. 2007) found reduced trunk diameter growth with increasing landscape planting depth when installing containergrown trees. However, landscape planting depth affected root system radius and root to shoot spread ratio (Table 4). Eight months after planting (May 2009), roots on magnolia that were planted 5 $\mathrm{cm}$ high in the landscape extended farther into the landscape than those planted deeply, generating a larger root to shoot spread ratio. But 14 months after planting, roots were beyond the edge of the crown (119 $\mathrm{cm}$ between trunk and root tips), and the difference between treatments was no longer significant (data not shown). Depth to the root collar was seven times greater for trees planted deeply in the landscape than shallow for all combinations of planting depth in nursery containers (Table 4); this was not surprising given the greater landscape planting depth. This strongly suggests that magnolia did not have the capacity to generate roots from the root collar after landscape planting under conditions of this study. Others showed that roots ceased growing from the collar as trees became 24 to 60 months old (Coutts et al. 1983; Lyons et al. 1987; Gilman and Harchick 2008).

Shallow roots growing tangent to the trunk over the main roots have been associated with reduced health on certain taxa attributable to setting the root collar deeply into the landscape (Wells et al. 2006), although other taxa have not been affected (Wells et al. 2006; Gilman and Grabosky 2011). Fewer roots

Table 4. Effect of landscape planting depth on magnolia growth and anchorage.

\begin{tabular}{|c|c|c|c|c|c|c|c|}
\hline $\begin{array}{l}\text { Landscape planting } \\
\text { depth }^{z}\end{array}$ & $\begin{array}{l}\text { Tree height } \\
\text { increase } 2012^{y} \\
(\mathrm{~m})\end{array}$ & \multicolumn{2}{|c|}{$\begin{array}{l}\text { Root system radius } \\
\text { eight months after } \\
\text { planting }(\mathrm{cm})\end{array}$} & \multicolumn{2}{|c|}{$\begin{array}{l}\text { Root:shoot eight months } \\
\text { after plantingw }\end{array}$} & \multicolumn{2}{|c|}{$\begin{array}{l}\text { Depth to root } \\
\text { collarv }^{\text {v }}(\mathrm{mm})\end{array}$} \\
\hline $5 \mathrm{~cm}$ high & $2.5 \mathrm{~b}^{\mathrm{r}}$ & $76 \mathrm{a}$ & & $0.71 \mathrm{a}$ & & $22 \mathrm{~b}$ & \\
\hline $10 \mathrm{~cm}$ deep & $2.7 \mathrm{a}$ & $59 \mathrm{~b}$ & & $0.56 \mathrm{~b}$ & & $156 \mathrm{a}$ & \\
\hline $\begin{array}{l}\text { Landscape planting } \\
\text { depth }\end{array}$ & \multicolumn{2}{|c|}{$\begin{array}{l}\text { Percent trunk with tangent/ } \\
\text { circling roots }(>10 \mathrm{~mm} \\
\text { diameter) within } 170 \mathrm{~L}^{\mathrm{u}}\end{array}$} & \multicolumn{2}{|c|}{$\begin{array}{l}\text { Total CSA roots growing up } \\
>20 \text { degree angle outside } 170 \mathrm{~L} \\
\text { container root ball }\left(\mathrm{mm}^{2}\right)\end{array}$} & \multicolumn{2}{|c|}{$\begin{array}{l}\text { Hinge point at five } \\
\text { degrees trunk pull } \\
(\mathrm{cm})\end{array}$} & $\begin{array}{l}\text { Rest angle after } \\
\text { winchings (degrees) }^{\text {s }}\end{array}$ \\
\hline $5 \mathrm{~cm}$ high & \multirow{2}{*}{\multicolumn{2}{|c|}{$\begin{array}{l}66 \mathrm{a} \\
43 \mathrm{~b}\end{array}$}} & \multicolumn{2}{|l|}{$380 \mathrm{~b}$} & \multicolumn{2}{|l|}{$18 \mathrm{a}$} & $1.1 \mathrm{a}$ \\
\hline $10 \mathrm{~cm}$ deep & & & \multicolumn{2}{|l|}{$972 \mathrm{a}$} & \multicolumn{2}{|l|}{$12 \mathrm{~b}$} & $0.8 \mathrm{~b}$ \\
\hline
\end{tabular}

${ }^{z}$ Root collar installed $5 \mathrm{~cm}$ above or $10 \mathrm{~cm}$ below landscape soil surface.

${ }^{y}$ Not significant $(P>0.10)$ for the years 2009-2011; trees installed September 2008.

${ }^{x}$ Distance between the edge of the planted $170 \mathrm{~L}$ root ball and the tip of the farthest root measured on the east and west side of tree.

${ }^{w}$ Ratio of distance between trunk and root tips to trunk and branch tips to the east and west.

${ }^{\mathrm{v}}$ Distance between top of mulch and root collar.

u Percent of trunk circumference with roots growing tangent to or circling trunk that touched or were embedded into the bark.

${ }^{t}$ Distance between trunk and the point where root plate dipped to its lowest point at five degrees tilt.

s Trunk angle relative to vertical start position after winch is released following five degree trunk tilt 68 months after planting.

${ }^{\mathrm{r}}$ Numbers followed by a different letter within columns are statistically different at $P<0.05 ; \mathrm{n}=24$, averaged across planting depth in nursery container and root pruning due to insignificant interactions $(P>0.19$ and 0.16 , respectively) with depth in the landscape. 
in the current study grew tangent to or circled the trunk when trees were installed deeper in the landscape (Table 4). A similar experiment in the same soil with Quercus virginiana (Gilman and Grabosky 2011), and other studies (Wells et al. 2006; Day and Harris 2008), clearly showed the opposite; i.e., more roots growing over the root collar when planting deep than shallow. Total CSA of roots growing up from deeper in the soil at more than a 20 degree angle increased nearly threefold when trees were installed deep $(10 \mathrm{~cm})$ compared to shallow $(5 \mathrm{~cm}$ high) in the landscape (Table 4). Perhaps roots growing up from the deeper portion of the root ball suppressed growth of surface roots close to the trunk, which could explain the fewer tangent roots growing over the root collar. Roots assembled at the bottom of a container root ball are often the oldest and largest (Gilman and Paz 2014), representing an established xylem connection to the root collar and trunk tissue. Therefore, these would be the roots expected to grow aggressively once planted, at least initially.

Trees planted $5 \mathrm{~cm}$ above landscape grade were slightly-but significantly-less stable in the landscape than trees planted deeper (10 $\mathrm{cm}$ deep), as indicated by a $35 \%$ larger rest angle following release of the winch after pulling to five degrees trunk tilt (Table 4). This suggested a slight shift of roots in the soil as a result of winching 40 months after landscape planting. The entire root ball sides on deeply planted trees rested against landscape soil providing greater resistance to winching than trees planted with $5 \mathrm{~cm}$ of the ball above landscape soil level; the soil over the root ball on deeply planted trees would add to root plate mass and therefore overturning resistance (Danjon et al. 2005). In contrast, the top $5 \mathrm{~cm}$ of the ball on shallowly planted trees would be pushing against the remnants of mulch, which would provide less resistance to winching than soil. However, the hinge point was farther from the trunk $(18 \mathrm{~cm})$ for trees planted high (5 $\mathrm{cm}$ above landscape grade) than those planted $10 \mathrm{~cm}$ deep $(12 \mathrm{~cm})$. The greater distance between trunk and hinge point suggests that anchorage could increase as trees grow (Danjon et al. 2005). In support of the hypothesis that trees can become better anchored with time, Gilman and Grabosky (2011) found Quercus virginiana (1.5 cm trunk caliper) installed at or slightly above grade were as well anchored 72 months later as trees planted $15 \mathrm{~cm}$ deep into field soil from $95 \mathrm{~L}$ containers. Others have also found reduced differences in anchorage between planting treatments as roots compensate over time (Nichols and Alm 1983).

\section{CONCLUSIONS}

Planting depth in nursery containers had no impact on anchorage 40 months after landscape planting or on trunk diameter 68 months after planting into landscape soil, regardless of landscape planting depth. However, deep planting in nursery containers was associated with more roots circling or growing tangent to the trunk over the root collar. Nursery planting depth interacted with root pruning at landscape planting - trees planted the deepest in nursery containers generated more roots growing upward into landscape soil, but only when root pruned at landscape planting. Planting deeply into the landscape appeared to slow surface root lateral expansion slightly in the first eight months after planting into this well-drained soil, but at 14 months after planting the root spread was similar regardless of landscape planting depth. In agreement with other studies, trunk diameter growth was not impacted by landscape planting depth. However, planting deeply can increase physiologically stress in finer-textured soil (Day and Harris 2008). Root ball shaving at landscape planting, which removed all roots on the container periphery (not the bottom), reduced the imprint left by the $170 \mathrm{~L}$ container measured 68 months later, but increased the amount of roots growing tangent to or circling the trunk. Removing roots over the root collar at time of planting can reduce amount of roots circling over the root collar (Harris and Day 2010) and may need to be combined with shaving the root ball periphery at planting to provide an effective treatment on container-grown trees. Improvement in root system architecture at the position of the $170 \mathrm{~L}$ container occurred at the expense of slightly slower trunk diameter growth (3\%) and a slight reduction in anchorage that might occur in an extreme weather event 40 months after planting. Results of this study may have been different in soils that drained poorly, or for different taxa, or if the study had been extended for a longer period with more taxa and more replicates. 
Acknowledgments. Thanks to innumerable growers in Florida and to the Florida Nursery Growers and Landscape Association for financial support for this research.

\section{LITERATURE CITED}

Anonymous. 2004. American Standard for Nursery Stock. American Nursery and Landscape Association, Washington D.C., U.S. $113 \mathrm{pp}$.

Anonymous. 2015. Florida Grades and Standards for Nursery Plants. Florida Department of Agriculture and Consumer Services, Division of Plant Industry. <www.freshfromflorida.com/ pi/pubs.html> (in press).

Arnold, M.A. 1996. Mechanical correction and chemical avoidance of circling roots differentially affect post-transplant root regeneration and field establishment of container-grown Shumard oak. Journal American Society Horticultural Science 121:258-263.

Arnold, M.A., G.V. McDonald, B.L. Bryan, G.C. Denny, W.T. Watson, and L. Lombardini. 2007. Belowgrade planting adversely affects survival and growth of tree species from five different families. Arboriculture \& Urban Forestry 33:64-69.

Arnold, M.A., and E. Young. 1991. $\mathrm{CuCo}_{3}$-painted containers and root pruning affect apple and green ash root growth and cytokinin levels. HortScience 26:242-244.

Brown, C., and K. Tilt. 1992. Effects of planting depth on three ornamental trees. Proceedings Southern Nurserymen Association $37: 2-4$.

Bryan, D.K., M.A. Arnold, A. Volder, W.T. Watson, L. Lombardini, L.J. Sloan, L.A. Valdez-Aguilar, and A.D. Cartmill. 2010. Planting depth during container production and landscape establishment affects growth of Ulmus parvifolia. HortScience 45:54-60.

Coutts, M.P. 1983. Development of the structural root system of Sitka spruce. Forestry 56:1-16.

Coutts, M.P., and B.C. Nicolle. 1991. Orientation of the lateral roots of trees. New Phytology 119:227-234.

Coutts, M.P., C.C.N. Nielson, and B.C. Nicolle. 1999. The development of symmetry, rigidity, and anchorage in the structural root system of conifers. Plant and Soil 217:1-15

Danjon F., T. Fourcaud, and D. Bert. 2005. Root architecture and wind-firmness of mature Pinus pinaster. New Phytology $168: 387-400$.

Day, S.D., and J.R. Harris. 2008. Growth, survival, and root system morphology of deeply planted Corylus colurna 7 years after transplanting and the effects of root collar excavation. Urban Forestry \& Urban Greening 7:119-128.

Fare, D. 2005. Should potting depth be a concern for container trees? pp. 25-28. In: G. Watson and A. Hewitt (Eds.). Trees and Planting: Getting the Roots Right Conference Proceedings. The Morton Arboretum, Lisle, Illinois, U.S.

Giblin, C., J. Gillman, D. Hanson, G.R. Johnson, and P. Weicherding. 2005. The effect of soil depth on the long-term health and frequency of storm damage to trees in the upper Midwest. pp. 33-39. In: G. Watson (Ed.). Trees and Planting: Getting the Roots Right Conference Proceedings. The Morton Arboretum, Lisle, Illinois, U.S.

Gilman, E.F. 2013. Anchorage influenced by production method and root pruning. Arboriculture \& Urban Forestry 39:1-5.

Gilman, E.F., and J. Grabosky. 2011. Quercus virginiana root attributes and lateral stability after planting at different depths. Urban Forestry \& Urban Greening 10:3-9.
Gilman, E.F., and C. Harchick. 2008. Planting depth in containers affects root form and tree quality. Journal of Environmental Horticulture 26:129-134.

Gilman, E.F., and C. Harchick. 2014. Root system morphology influences lateral stability of Swietenia mahogani. Arboriculture \& Urban Forestry 40:27-35.

Gilman, E.F., C. Harchick, and M. Paz. 2010a. Planting depth affects root form of three shade tree cultivars in containers. Arboriculture \& Urban Forestry 36:132-139.

Gilman, E.F., and M.E. Kane. 1990. Root growth of red maple following planting from containers. HortScience 25:527-528.

Gilman, E.F., and F.J. Masters. 2010. Effect of tree size, root pruning, and production method on root growth and lateral ability of Quercus virginiana. Arboriculture \& Urban Forestry 36:281-291.

Gilman, E.F., and M. Paz. 2014. Root system morphology influenced by container design, retention time, and root pruning. Arboriculture \& Urban Forestry 40:16-26.

Gilman, E.F., M. Paz, and C. Harchick. 2010b. Root ball shaving improves root systems on seven species in containers. Journal of Environmental Horticulture 28:13-18.

Gilman, E.F., M. Paz, and C. Harchick. 2015. Nursery planting depth, mulch application, and root pruning at landscape planting affect tree health and anchorage. Arboriculture \& Urban Forestry 41(2):75-57.

Gilman, E.F., and C. Wiese. 2012. Root pruning at planting and planting depth in the nursery impact root system morphology and anchorage. Arboriculture \& Urban Forestry 38:229-236.

Harris, J.R., and S. Day. 2010. Planting depth at onset of container production and subsequent root ball remediation at transplanting of pin oak and linden. HortScience 45:1793-1797.

Harris, R.W., W.B. Davis, N.W. Stice, and D. Long. 1971. Influence of transplanting time in nursery production. Journal American Society for Horticulture Science 96:109-110.

Hewitt, A., and G.W. Watson. 2009. Bare root liner production can alter tree root architecture. Journal of Environmental Horticulture 27:99-104.

Krasowski, M.J., and J.N. Owens. 2000. Morphological and physical attributes of root systems and seedlings growth in three different Picea glauca reforestation stock. Canadian Journal Forestry Research 30:1669-1681.

Lyons, C.G., Jr., R.E. Byers, and K.S. Yoder. 1983. Influence of planting depth on growth and anchorage of young 'Delicious' apple trees. HortScience 18:923-924.

Lyons, C.G., Jr., R.E. Byers, and K.S. Yoder. 1987. Influence of planting depth on growth of young apple trees. Journal of Environmental Horticulture 5:163-164.

Nichols, T.J., and A.A. Alm. 1983. Root development of containerreared, nursery-growth, and naturally regenerated pine seedlings. Canadian Journal of Forest Research 13:239-245.

Persson, P. 1978. Some possible methods of influencing the root development of containerized tree seedlings. pp. 295-300. In: Proceedings of the Symposium on Root Form of Planted Trees, Victoria, B.C., Canada. May 16-19.

Salonius, P., K. Beaton, and B. Roze. 2000. Effects of cell size and spacing on root density and field performance of containerreared black spruce. Information Report M-X-208E, Canadian Forest Service, Atlantic Forestry Centre, Frederickton, New Brunswick, Canada.

Schwan, T. 1994. Planting depth and its influence on survival and growth: A literature review with emphasis on Jack pine, black 
spruce, and white spruce. Northeast Science and Technology Technical Report TR-017.

Tate, R.L. 1980. Detection, description and treatment of girdling roots on urban Norway maple trees. Ph.D. Thesis, University of Michigan.

Watson, G.W., and S. Clark. 1993. Regeneration of girdling roots after removal. Journal of Arboriculture 19:278-280.

Watson, G.W., and T.D. Sydnor. 1987. The effect of root pruning on the root system of nursery trees. Journal of Arboriculture 13:126-130.

Weicherding, P.J., C.P. Giblin, J.H. Gillman, D.L. Hanson, and G. Johnson. 2007. Mechanical root-disruption practices and their effect on circling roots of pot-bound Tilia cordata Mill. and Salix alba L. 'Niobe'. Arboriculture \& Urban Forestry 33:43-47.

Wells, C., C.E.K.S. Townsend, J.D. Caldwell, D.L. Ham, M. Sherwood, and E.T. Smiley. 2006. Effects of planting depth on landscape tree survival and girdling root formation. Arboriculture \& Urban Forestry 32:305-311.

Edward F. Gilman (corresponding author)

University of Florida

Environmental Horticulture

1533 Fifield Hall

Gainesville, Florida 32611, U.S.

egilman@ufl.edu

Maria Paz

University of Florida

Environmental Horticulture

1533 Fifield Hall

Gainesville, Florida 32611, U.S.

Chris Harchick

University of Florida

Environmental Horticulture

1533 Fifield Hall

Gainesville, Florida 32611, U.S.

Résumé. Des plants ont été cultivés selon une combinaison de divers facteurs de profondeur de plantation dans des contenants de pépinière puis ont été transplantés en plein sol dans un aménagement afin dévaluer les impacts sur l'architecture racinaire, sur la croissance et sur la stabilité mécanique du Magnolia grandiflora L. La profondeur de plantation dans les contenants puis en plein sol n'a eu aucun impact sur la contrainte de flexion requise pour faire incliner les troncs 40 mois après leur plantation en plein sol et n'a eu aucun impact tant sur le diamètre du tronc que sur la hauteur des arbres 68 mois plus tard. Les arbres plantés à $128 \mathrm{~mm}$ de profondeur dans des contenants de $170 \mathrm{~L}$ présentaient plus de racines encerclantes au-moment de leur plantation en plein sol et 68 mois plus tard que les arbres plantés moins profondément dans des contenants. La taille des racines au moment de la plantation en plein sol réduit d'un tiers la cote d'influence de la profondeur de plantation en contenant sur le système racinaire en comparaison avec l'absence de taille des racines, réduisant de seulement $4 \mathrm{~mm}$ la croissance en diamètre du tronc sur une période de 68 mois. La qualité du développement de l'architecture racinaire à la suite de la taille des racines excède vraisemblablement les inconvénients rarement rencontrés d'un ancrage au sol moindre dans les conditions climatiques extrêmes simulées par le treuillage des troncs. Les arbres plantés 5 $\mathrm{cm}$ au-dessus du niveau du sol étaient légèrement, mais significati- vement, moins stables que les arbres plantés plus profondément (10 $\mathrm{cm}$ sous le niveau du sol). La taille des racines à la plantation afin d'éliminer les racines sur le pourtour de la motte semble améliorer le développement racinaire et ne cause qu'un léger impact sur la croissance future et l'ancrage au sol des arbres.

Zusammenfassung. Um Effekte auf die Wurzelarchitektur, Wachstum und mechanische Stabilität von Magnolia grandiflora L. zu studieren, wurden Pflanzen in 2 x 2 fakturiellen Kombinationen von Pflanztiefen in Baumschulcontainern und bei einer Landschaftsinstallation aufgezogen. Die Pflanztiefe in dem Container oder dem Pflanzbeet hatten keinen Einfluss auf den Biegestress, der aufgewendet wurde, um die Stämme 40 Monate nach der Auspflanzung zu biegen und beeinflussten weder den Stammdurchmesser noch die Baumhöhe 68 Monate später. Bäume, die ca. $128 \mathrm{~mm}$ tief in $170 \mathrm{l}$ Container gepflanzt wurden, hatten mehr Würgewurzeln als die ausgepflanzten und 68 Monate später als die Bäume, die flach in die Container gepflanzt wurden. Der Wurzelschnitt vor der Auspflanzung in die Landschaft reduzierte den Einfluss des verwendeten Containers auf das Wurzelsystem um ein Drittel von dem ungeschnittener Wurzeln mit nur einer $4 \mathrm{~mm}$ Reduktion des Stammdurchmesserzuwachses über 68 Monate. Eine Verbesserung der Wurzelarchitektur durch Wurzelschnitt begünstigt möglicherweise die selten vorkommenden Schattenseiten der etwas geringeren Verankerung in einer extremen Wetterlage, die durch eine Seilwinde simuliert wird. Bäume, die $5 \mathrm{~cm}$ oberhalb der Stufe gepflanzt wurden waren etwas - aber signifikant - weniger stabil in der Landschaft als tiefer gepflanzte Bäume (10 cm unter der Stufe). Ein Wurzelschnitt bei der Pflanzung, um die Wurzel an der Peripherie des Wurzelballens zu entfernen, schien die Wurzelarchitektur zu verbessern, während das Wachstum und die Verankerung nur wenig beeinflusst wurden.

Resumen. Las plantas se cultivaron en una combinación factorial de $2 \times 2$ de profundidad de plantación en contenedores de vivero y en una instalación en el paisaje para estudiar los efectos sobre la arquitectura de la raíz, el crecimiento y la estabilidad mecánica de Magnolia grandiflora L. La profundidad de plantación en los contenedores o el suelo del paisaje no ha tenido ningún impacto en la flexión para la inclinación de troncos 40 meses después de la plantación en el paisaje, y no impactó el crecimiento del diámetro del tronco ni la altura del árbol 68 meses más tarde. Los árboles plantados a $128 \mathrm{~mm}$ de profundidad en contenedores de $170 \mathrm{~L}$ tuvieron más raíces enrolladas en la plantación en el paisaje 68 meses más tarde que los árboles plantados en contenedores poco profundos. La poda de las raíces en la plantación en el paisaje redujo la huella en el sistema de la raíz en el contenedor a un tercio, mientras que la ausencia de poda de raíces con solamente reducción de $4 \mathrm{~mm}$ en el crecimiento del diámetro del tronco después de 68 meses. El mejoramiento en la arquitectura de la raíz debido a la poda probablemente sea mayor que el lado negativo toda vez que se encuentra un poco menos de anclaje en un evento simulado por tensión de los troncos. Los árboles plantados $5 \mathrm{~cm}$ por encima del nivel fueron ligeramente, pero significativamente- menos estables en el paisaje que los árboles plantados más profundamente $(10 \mathrm{~cm}$ por debajo del nivel). La poda de raíces en la plantación para eliminar raíces en la periferia del cepellón pareció mejorar la arquitectura de raíz impactando ligeramente el crecimiento y anclaje. 